\title{
Suppression of DNA Synthesis in Phytohaemagglutinin Stimulated Lymphocytes by Prednisone Treatment
}

Successful chemotherapy of leukemia is dependent on a clear understanding of the degree of action of the antileukemic drugs. The present preliminary communication deals with the extent to which prednisone therapy depresses DNA synthesis in phytohemagglutinin (PHA) stimulated blast cells in leukemic children.

Materials and Methods. Peripheral blood leucocyte cultures were set up ${ }^{1}$ from 2 children with acute lymphocytic leukemia. Both were in clinical relapse at the time of investigation; one being newly diagnosed and untreated, the other having relapsed after 6 months on prednisone therapy ( $2 \mathrm{mg} / \mathrm{kg}$ body weight). Both these patients are now deceased.

Cultures were incubated for $68 \mathrm{~h}$ after which tritiated thymidine $(1 \mu \mathrm{c} / \mathrm{ml}$, specific activity $1.9 \mathrm{C} / \mathrm{m} M)$ was added. For the $2 \mathrm{~h}$ continuous labelling experiment, colchicine $(0.1 \mathrm{ml} / \mathrm{ml}$ of a $0.3 \%$ solution) was added at the same time as the tritiated thymidine; for the $4 \mathrm{~h}$ continuous labelling experiment, colchicine was added $2 \mathrm{~h}$ before
Discussion and conclusions. Anti-leukemic therapy is usually aimed at destroying the neoplastic leukemic blast cells, or sufficiently suppressing its metabolic activities as to render their existence short-lived. The circulating leucocytes also inevitably became affected, resulting in a slower rate of DNA synthesis and mitotic activity. This is compatible with the results obtained in the present experiments in which prednisone treatment has caused a significant $(P<0.001)$ depression in the DNA synthesis in apparently normal transformed 'blastoid' cells. Since the cells from both patients are transformed blast cells, the difference in cellular DNA activity observed in the treated and untreated child is due to the prednisone therapy and not to any difference in metabolic activities of the cells. No significant difference had been observed in the labelling indices, hence it is evident that blastoid transformation and DNA synthesis are not completely blocked, but that DNA synthesis continues at a slower rate with a corresponding increase in the generative cycle of the cell.

Details of grain counts and labelling indices

\begin{tabular}{|c|c|c|c|c|c|c|c|c|}
\hline \multirow{2}{*}{$\begin{array}{l}\text { Labelling } \\
\text { time }\end{array}$} & \multirow[t]{2}{*}{ Range } & \multicolumn{3}{|c|}{ Untreated } & \multirow[t]{2}{*}{ Range } & \multicolumn{3}{|l|}{ Treated } \\
\hline & & Mean & S.D. & $\begin{array}{l}\text { Labelled } \\
\text { mitosis }\end{array}$ & & Mean & S.D. & $\begin{array}{l}\text { Labelled } \\
\text { mitosis }\end{array}$ \\
\hline $2 \mathrm{~h}$ & $90-152$ & 64.5 & \pm 35.7 & $80 \%$ & & No labelling & & \\
\hline $4 h$ & $200-460$ & 248.6 & \pm 40.8 & $86.6 \%$ & $70-192$ & 128.7 & \pm 29.2 & $80.3 \%$ \\
\hline
\end{tabular}

termination of the cultures. Auto-radiographic treatment of the cells then followed the method described by Yun Is ${ }^{2}$.

The percentage of labelled mitoses was calculated and the number of grains of each of 50 metaphases was counted. This was done from the cultures of both the treated and untreated patients for the 2 and $4 \mathrm{~h}$ experiments.

Results. 2-h labelling: The grains per metaphase cell in the untreated case varied from 90-152 (S.D. \pm 35.7 ). Percentage of labelled mitoses (labelling index) was $80 \%$. No labelling was obtained from the cultures of the treated case (Table). 4-h labelling: The grains per metaphase cell from the untreated case varied from $200-460$ (S.D. \pm 40.8 ) and the labelling index was $86.6 \%$. In the treated case the grain count varied from 70-192 (S.D. \pm 29.2) and the labelling index was $80.3 \%$.
Résumé. Recherches autoradiographiques faites sur des cultures de sang périphérique de deux enfants leucémiques, l'un traité et l'autre non traité au prednisone. Un abaissement significatif de la synthèse DNA s'est produit après $68 \mathrm{~h}$ dans la culture du cas traité.

N. P. BISHUN ${ }^{3}$

Institute of Child Health, London, W.C.1. (England), 1 March 1968.

1 N. P. Bishun, W. R. M. Morton and B. McLaverty, Lancet 2, 315 (1964).

2 J. J. Yunis, Human Chromosome Methodology (Academic Press, London 1966), p. 91.

3 Beit Memorial Research Fellow.

\section{Suppression of Experimental Allergic Encephalomyelitis by Vitamin A}

The experimental allergic encephalomyelitis (EAE) is an autoimmune process which may be readily induced in various animals by inoculating a homogenate of central nervous system tissue, emulsified in Freund's complete adjuvant. It is assumed that tissue damage in EAE appears as a result of a delayed hypersensitivity reaction between sensitized cells and the encephalitogenic antigen from the nervous tissue ${ }^{1}$ but the intimate mechanism of the delayed hypersensitivity is unknown.

An increase in the catheptic and acid phosphatase activity in the brain of animals with EAE has been found ${ }^{\mathbf{2} 3}$. These enzymes are secluded in lysosomes and for this reason we found it tempting to investigate the participation of lysosomes in the pathogenesis of EAE. Large amounts of vitamin A release the lysosomal enzymes into the cell sap and the serum ${ }^{4}$. Therefore we studied the influence of high doses of vitamin A upon EAE in guinea-pigs.

Three groups of guinea-pigs, of both sexes, weighing 450-530 g were experimented upon. The animals were observed for 3 weeks before the beginning of the experiment. The first group (A) contained 13 animals, the 